\title{
KESEJAHTERAAN EKONOMI MASYARAKAT PESERTA PELATIHAN KELOMPOK PRAKOPERASI DI KECAMATAN NAMLEA KABUPATEN BURU
}

\section{THE ECONOMIC WELFARE OF THE COMMUNITY MEMBERS JOINING THE PRE-COOPERATIVE GROUP TRAINING IN NAMLEA DISTRICT, BURU REGENCY}

\author{
Ateng Wesa, Yoyon Suryono \\ MAN 2 Ambon, Universitas Negeri Yogyakarta \\ Ateng.wesa@yahoo.com, yoyonsuryono@yahoo.com
}

\begin{abstract}
Abstrak
Penelitian ini bertujuan untuk mengetahui proses pembentukan kelompok prakoperasi di Kecamatan Namlea, faktor pendukung dan penghambat pelatihan kelompok prakoperasi di Kecamatan Namlea, dandampak pelatihan terhadap anggota kelompok Prakoperasi di Kecamatan Namlea. Penelitian ini merupakan penelitian kasus dengan pendekatan kualitatif naturalistik. Data yang diperoleh dianalisis secara interaktif dengan tahap pengumpulan data, reduksi data, penyajian data dan penarikan kesimpulan. Hasil penelitian menunjukkan bahwa kelompok prakoperasi dibentuk dari organisasi kelompok masyarakat yang memiliki pola pikir yang sama, dengan bantuan dari Dinas Koperasi lewat sosialisasi tentang proses pembentukan prakoperasi dan syarat-syarat yang harus dipenuhi untuk mendirikan prakoperasi. Biaya pelatihan disediakan oleh pemerintah daerah Kabupaten Buru masih kurang sehingga waktu pelatihan terbatas sedangkan fasilitator sudah baik. Diklat yang dilaksanakan disambut baik oleh peserta dari kelompok prakoperasi karena materi yang diberikan disesuaikan dengan kebutuhan peserta pelatihan dilapangan dalam mengelola usaha atau membuka usaha baru. Pelaksanaan pelatihan didukung oleh biaya dari pemerintah daerah Kabupaten Buru, memiliki fasilitator pelatihan yang memadai dan didukung oleh peserta pelatihan yang memilik motivasi untuk belajar agar dapat menambah pengetahuan dan keterampilan dalam mengelola koperasi maupun usaha sendiri.Kontribusi pelatihan terhadap peserta pelatihan adalah dapat meningkatkan sumber daya manusia (SDM), membangkitkan semangat untuk berkoperasi dan berwirausaha, serta membantu masyarakat khususnya anggota kelompok prakoperasi dalam meningkatkan ekonomi keluarganya. Namunkurang transparansi keuangan dari pengurus kepada anggota sehingga banyak koperasi yang kurang berkembang.
\end{abstract}

Kata kunci: pelatihan, kelompok prakoperasi

\section{Abstract}

This research was aimed to know: the process of forming of pre-cooperative group in Namlea District, supportingand obstacle factors and of pre-cooperative group training in Namlea District, training effects towards pre-cooperative groups in Namlea District. This was a case research using a qualitative naturalistic approach. Data obtained was analyzed interactively by steps ofdata gathering, data reduction, data presentation and, drawing conclusion. The research result showed that precooperative groups was established from community group organization that had the same patterned thinkers with the aids of Cooperative Office through a socialization on pre-cooperative establishment process and requirements to fulfill to establish a pre-cooperative. Training fee provided by Buru Regency regional government was still less so that training time was limited, while the facilitators had been good. The education and training conducted was well welcomed by the training participants from pre-cooperative groups due to the modules given was adjusted to field training participant needs in managing business and run new businesses. The training enforcement was aided by Buru Regency regional governmental that had adequate training facilitators and supported by training participants who were motivated to learn in order that they could increase knowledge and skills to manage a cooperative as well as self business. The training contribution towards training participants was to be able to improve human resources (SDM), ignited enthusiasm to run cooperative and to do business and also to help people, especially pre-cooperative group members to improve their family economics. However, the lack of financial transparency from the co-operative administrators to the members so that a lot of cooperatives were less-developed.

Keywords: training, pre-cooperative groups. 


\section{PENDAHULUAN}

Kesulitan untuk memenuhi kebutuhan hidup yang dialami oleh masyarakat menimbulkan kemiskinan. Apabila kita melihat secara menyeluruh kebutuhan utama (pokok) dan kebutuhan tambahan, penduduk di negara ini kemiskinan masih tergolong tinggi. Kemiskinan bukan kekurangan sandang dan pangan saja, tetapi juga pemukiman yang sehat, pendidikan, hukum dan kekurangan komunikasi.

Badan Pusat Statistik Indonesia memperkirakan jumlah masyarakat yang tergolong miskin pada tahun 2011 mancapai 30,02 juta orang atau $12,49 \%$ dan pada tahun 2012 masyarakat miskin mencapai 29,13 juta orang atau $11,96 \%$. Hal tersebut sangat memprihatinkan masyarakat Indonesia yang terbelenggu dalam kemiskinan. Untuk mengurangi kemiskinan pemerintah melakukan langkah-langkah penanganan kemiskinan antara lain melalui Dinas Koperasi dan Usaha Kecil Menengah (UKM) dengan berbagai inovasi untuk membangun kekuatan ekonomi dari berbagai lapisan masyarakat sebagai penggerak perekonomian nasional yang dimulai dari lapisan masyarakat paling bawah.

Usaha pemerintah dalam pengentasan kemiskinan dengan program pengembangan Koperasi dan UKM telah mengalami peningkatan Pada tahun 2010, jumlah Koperasi dan UKMsebanyak 177. 482 unit, jumlah itu bertambah 4,15\%. Pada tahun 2011, jumlah Koperasi dan UKM mencapai 188.181 unit atau naik $6,03 \%$ dari tahun sebelumnya.Pada tahun 2012 jumlah Koperasi dan UKM mencapai 192.443 unit dengan jumlah anggotanya mencapai 33,68 juta orang

Proses percepat pertumbuhan koperasi di Indonesia dilaksanakan dengan strategi tertentu. Demikian pula dengan Provinsi Maluku sebagai salah satu propinsi di Indonesia merupakan salah satu daerah yang cukup potensial dalam pertumbuhan dan pengembangan koperasi. Dalam konsep strategi pengembangan koperasi di daerah Maluku secara umum dan khusus pada Kabupaten Buru, koperasi dapat mengembangkan perekonomian rakyat dalam meningkatkan kesejahteraan anggota koperasi. Pengembangan koperasi di pulau Buru bersandar pada konsep-konsep pengembangan koperasi secara nasional dan disinergikan dengan budaya daerah, kebiasaan penduduk untuk mempertahankan hidup menjadi pertimbangan praktis dalam pengembangan koperasi untuk dapat memperbaiki taraf kesejahteraan ekonomi anggota dan masyarakat umum.

Dinas Koperasi Kabupaten Buru berupaya mengembangkan koperasi untuk meningkatkan kesejahteraan ekonomi masyarakat miskin. Salah satu bentuk upaya tersebut adalah mendirikan prakoperasi dan pelaksanaan program pendidikan dan pelatihan kepada anggota prakoperasi. Kegiatan pendidikan dan pelatihan merupakan salah satu prasyarat dalam pendirian prakoperasi. Langkah ini sangat penting sebagai upaya dan kesiapan anggota prakoperasi yang secara bersama mengatur rencana dan strategi dari kelompok prakoperasi yang bergerak dalam bentuk usaha kecil dan menengah yang berada di masyarakat. Pengembangan koperasi di Kecamatan Namlea memberi kontribusi bagi anggotanya untuk meningkatkan ekonomi keluarga, melalui usaha prakoperasi dibidang simpan pinjam yang diperuntukan bagi anggotanya untuk membuka usaha maupun mengembangkan usaha yang telah ada.

Prinsip dan asas koperasi meliputi pengelolaan usaha, tantangan dan peluang menjadi bahan pertimbangan dalam proses pembentukan koperasi.Oleh karena itu apabila ada usulan dari masyarakat untuk mendirikan koperasi, Pemerintah Kabupaten Buru dalam hal ini Dinas Koperasi lebih menekankan pada kegiatan prakoperasi yang mencakup persyaratan yang harus dipenuhi oleh anggota prakoperasi, termasuk mengikuti pendidikan dan pelatihan untuk pengembangan prakoperasi menjadi koperasi. Setelah kegiatan pelatihan dilaksanakan belum pernah diadakan evaluasi terhadap dampak pelatihan terhadap anggota prakoperasi baik dari dinas koperasi maupun dari pihak lain. Oleh karena itu dipandang perlu dilakukan penelitian tentang pengaruh pelatihan terhadap kesejateraan ekonomi bagi masyarakat yang telah meng- 
ikuti pelatihan prakoperasi. Tujuan penelitian ini adalah mendeskripsikan proses pembentukan kelompok prakoperasi di Kecamatan Namlea mendeskripsikan faktor pendukung dan penghambat pelatihan kelompok prakoperasi di Kecamatan Namlea, dan menjelaskan dampak pelatihan terhadap anggota kelompok prakoperasi di Kecamatan Namlea

Huraerah (2011, p.29) mengatakan bahwa individu, keluarga atau masyarakat yang mengatasi masalah sosialnya lebih sejahtera. Begitu pula, individu, keluarga atau masyarakat yang kebutuhannya terpenuhi, seperti kebutuhan makanan, pakaian, rumah, pendidikan, kesehatan, air bersih, dan transportasi akan merasa sejahtera. Demikian pula, individu, keluarga atau masyarakat menjadi sejahtera jika memiliki kesempatan sosial untuk mengembangkan dan merealisasikan potensi-potensinya.

Berdasarkan Undang-Undang No.11 Tahun 2009 Pasal 1 Ayat 1, kesejahteraan sosial adalah kondisi terpenuhinya kebutuhan material, spiritual, dan sosial warga negara agar dapat hidup layak dan mampu mengembangkan diri, sehingga dapat melaksanakan fungsi sosial. Perserikatan Bangsa-Bangsa (Suharto,2010, p.1) memberikan batasan kesejahteraan sosial sebagai kegiatan-kegiatan yang terorganisasi yang bertujuan untuk membantu individu atau masyarakat guna memenuhi kebutuhan-kebutuhan dasarnya dan meningkatkan kesejahteraan selaras dengan kepentingan keluarga dan masyarakat.

Merujuk pada penjelasan Spicker (Suharto, 2010, p.9) mengenai konsep welfare berarti"the provision of social services provided by the state" dan sebagai "certain types of benefits, especially meanstested social security, aimed at poor people". Artinya pembangunan kesejahteraan sosial menunjuk pada pemberian pelayanan sosial yang dilakukan oleh negara atau jenis-jenis tunjangan tertentu, khususnya jaminan sosial yang ditujukan bagi orang miskin.

Sulistiati (Huda, 2009, p.73) mengatakan bahwa, kesejahteraan sosial adalah keseluruhan usaha sosial yang terorganisir dan mempunyai tujuan utama untuk meningkatkan taraf hidup masyarakat berdasarkan konteks sosialnya. Di dalamnya tercakup pula unsur kebijakan dan pelayanan dalam arti luas yang terkait dengan berbagai kehidupan dalam masyarakat, seperti pendapatan, jaminan sosial, kesehatan, perumahan, pendidikan, rekreasi budaya, dan lain sebagainya. Lebih lanjut dalam konteks Indonesia sendiri kesejahteraan sosial dapat dimaknai terpenuhinya kebutuhan seseorang, kelompok, atau masyarakat dalam hal material, spiritual maupun sosial.

Berdasarkan penjelasan tersebut, maka kesejahteran sosial merupakan suatu bentuk pemenuhan kebutuhan hidup manusia yang berlangsung secara sistematis, baik yang terjadi pada lembaga-lembaga sosial maupun di kelompok-kelompok yang ada dalam masyarakat, untuk memenuhi kebutuhan hidup perorangan, keluarganya dan masyarakat.

Selain kesejahteraan sosial juga ada kesejateraan ekonomi. Ilmu ekonomi normatif (normative economics) yang berkaitan dengan atau mempelajari tentang yang seharusnya atau bagaimana masalah-masalah ekonomi yang dihadapi oleh masyarakat seharusnya diselesaikan (Salvatore, 2006, p.2).

Rintuh dan Miar (2009, pp.13-14) menjelaskan bahwa konsep ekonomi yang dimaksud adalah konsep ekonomi kesejahteraan (welfare economics). Perkembangan konsep ekonomi kesejahteraan menjadi teori kebijaksanaan ekonomi yang menarik untuk dipahami dalam usaha membandingkan apakah kondisi perekonomian menjurus ke keadaan yang lebih baik atau sebaliknya. Beberapa konsep tentang kriteria kesejahteraan masyarakat bermanfaat bagi para pengambil keputusan dan kebijakan ekonomi terutama dalam pemberdayaan ekonomi rakyat

Tugas pokok dari welfare economic adalah membanding-bandingkan berbagai kondisi perekonomian (economic state) untuk menentukan apakah perubahan kondisi suatu perekonomian menjurus kearah yang lebih baik atau sebaliknya. Tujuan dari welfare economic adalah mengevaluasi keinginan masyarakat terhadap berbagai pernyataan atau kebijaksanaan ekonomi, demi- 
kian Henderson dan Quandt (Rintuh \& Miar, 2009, p.15).

Sesuai dengan penjelasan tersebut, teori ekonomi kesejahteraan mempelajari berbagai kondisi di mana cara penyelesaian dari model ekuilibrium umum dapat dikatakan optimal. Hal tersebut memerlukan lokasi optimal faktor produksi diantara komoditi dan alokasi optimal komoditi, yaitu distribusi pendapatan diantara konsumen (Salvatore, 2006, p.244).

Pusat perhatian dari kajian para ekonom adalah pertukaran ekonomi, pasar, dan ekonomi. Sedangkan masyarakat dianggap sebagai sesuatu yang luar, dipandang sebagai sesuatu yang telah ada (given). Sebaliknya, sosiologi memandang ekonomi sebagai bagian integral dari masyarakat. Sumarto (2010, p.34) menjelaskan bahwa, di dalam ilmu ekonomi, pola konsumsi mayarakat sangat diperhatikan karena konsumsi masyarakat merupakan salah satu indikator keberhasilan pembangunan perekonomian. Semakin besar konsumsi masyarakat maka hal tersebut mengindikasikan pertumbuhan ekonomi yang sekian besar pula.

Dapat dikatakan bahwa ekonomi rakyat adalah segala kegiatan dan upaya rakyat untuk memenuhi segala kebutuhan hidupnya yaitu dengan, pangan, papan, pendidikan dan kesehatan. Dengan kata lain, ekonomi rakyat adalah kegiatan ekonomi yang dilakukan oleh rakyat dengan mengelola sumber daya yang dapat dikuasainya, dan ditunjukan untuk memenuhi kebutuhan dasar beserta keluarganya. Dalam konteks permasalahan yang sederhana, ekonomi rakyat adalah strategi bertahan hidup (survival) dari rakyat miskin (Rintuh \& Miar, 2009, p.4).

Mubyarto (Hamid, 2012, pp.8-9) mengatakan bahwa ekonomi rakyat adalah kancah kegiatan ekonomi bagi masyarakat kecil, orang kecil, Wong cilik, yang merupakan kegiatan keluarga, tidak merupakan usaha formal berbadan hukum, tidak juga secara resmi diakui sebagai sektor ekonomi yang berperan penting dalam perekonomian nasional. Dalam literatur ekonomi pembangunan disebut sebagai sektor informal, "underground economy", atau "extralegal sector". Dalam demokrasi ekonomi Indo- nesia produksi tidak hanya dikerjakan oleh sebagian warga tetapi oleh semua warga masyarakat, dan hasilnya dibagikan kepada anggota masyarakat secara adil dan merata.

Sumarto (2010, p.96) menambahkan bahwa dalam menjalankan roda perekonomian yang berdasarkan kepentingan masyarakat, tata nilai dalam kehidupan ekonomi yang kokoh. Ekonomi yang berbasis kerakyatan tidak hanya mementingkan kepentingan segelintir atau sekelompok kecil masyarakat yang memegang modal dalam skala mayoritas. Ekonomi yang berbasis nilai-nilai kerakyatan harus bisa menjembatani dan menggerakan komunitas ekonomi "kelas bawah" dalam hal ini Koperasi dan UMKM menjadi ekonomi "kelas menengah" atau bahkan "kelas atas.

Sesuai dengan penjelasan tersebut maka disimpulkan, yang berkaitan dengan ekonomi rakyat atau masyarakat meliputi dua hal yaitu masyarakat harus mendapat jaminan untuk bisa mendapatkan pekerjaan yang dianggap layak dan sesuai dengan keadaan mereka. Maupun mencipta pekerjaan agar dapat meningkatnya daya beli masyarakat sehingga angka pertumbuhan ekonomi masyarakat meningkat.

Peningkatan ekonomi kerakyatan harus diimbangi dengan peningkatan sumber daya manusia. Oleh karena itu pemerintah mengupayakan dengan mengadakan pelatihan bagi kelompok masyarakat untuk meningkatkan sumber daya manusia. Flippo (Kamil, 2012, p.3) mengemukakan bahwa "training is the act increasing the knowledge and skill of an employee for doing a particular job" Pelatihan adalah tindakan meningkatkan pengetahuan dan keterampilan seorang pegawai untuk melaksanakan tugas tertentu. Hal senada ditambahkan oleh Beach (Kamil, 2012, p.10) yaitu "The objective of training is to achieve a change in the behavior of those training". Tujuan pelatihan adalah untuk memperoleh perubahan dalam tingkah laku mereka yang terlatih. Seiring dengan pengertian tersebut dapat disimpulkan bahwa pelatihan kaitannya dengan pekerjaan tertentu, pada kenyataannya tidak selalu dikaitkan bagi pegawai, tetapi juga dapat dikaitkan dengan pekerjaan yang dilakukan oleh setiap orang sehari-hari, baik 
dalam lingkungan organisasi maupun usaha pribadi. Bhatti dan Kaur (2010, p.1) menjelaskan pelatihan merupakan salah satu teknik pengembangan sumber daya manusia yang paling penting dan dapat diandalkan untukmeningkatkan produktivitas organisasi dan karyawan.

Dalam Inpres No 15 Tahun 1974, pengertian pelatihan adalah bagian dari pendidikan yang menyangkut proses belajar untuk memperoleh dan meningkatkan pengetahuan dan keterampilan, berlaku dalam waktu relatif singkat dengan metode mengutamakan praktik dari pada teori. Pelatihan memiliki dua sasaran, yakni partisipasi dan organisasi. Kegiatan pelatihan diharapkan terjadi perbaikan tingkah laku pada partisipan pelatihan yang sebenarnya merupakan anggota suatu organisasi, dan yang kedua perbaikan organisasi itu sendiri, yakni agar menjadi efektif.

Mujiman (2011, p.58) mengungkapkan bahwa menetukan kebutuhan pelatihan bukan hal sederhana sebab kebutuhan pelatihan terkait dangan siapa yang dilatih, tujuan pelatihan; untuk kebutuhan siapa pelatihan itu dilakukan, siapa penyelenggara pelatihan, dan merupakan paket yang tak dapat dipecah-pecah sesuai dengan keinginan pembelajar (teacher-controlled), ataukah dapat dipilih materinya oleh pembelajar sendiri (learner-controlled).

Pelatihan tidak bermanfaat jika peserta tidak mendapatkan kemampuan atau motivasi untuk mendapatkan keuntungan darinya. Berkaitan dengan kemampuan, peserta butuh (di antara hal-hal lain) bacaan yang disyaratkan, keterampilan menulis dan metematika, dan persyaratan tingkat pendidikan intelegensi, dan pengetahuan dasar. Oleh karena itu, apabila seseorang sangat menginginkan sesuatu, jalan nampaknya terbuka untuk memperolehnya dan yang bersangkutan berupaya mendapatkannya.

Siagian (2008, p.292) menjelaskan dengan cara yang sangat sederhana, teori harapan bermakna bahwa jika seseorang menginginkan sesuatu dan memperoleh sesuatu itu cukup besar, yang bersangkutan sangat terdorong untuk memperoleh hal yang diinginkannya itu. Sebaliknya, jika harapan memperoleh hal yang diinginkan- nya itu tipis, motivasinya pun untuk berupaya menjadi rendah. Dari penjelasan diatas bila dikaitkan dengan koperasi sangat memiliki hubungan dengan motivasi anggota koperasi untuk memenuhi kebutuhan hidup kearah yang lebih baik. Hatta (Baswir, 2012, p.2) menjelaskan bahwa Koperasi didirikan sebagai persekutuan kaum yang lemah untuk membela keperluan hidupnya. Mencapai keperluan hidupnya dengan ongkos yang semurah-murahnya itulah yang dituju. Pada koperasi didahulukan keperluan bersama, bukan keuntungan.

Lebih lanjut Baswir (2012, p.68) menjelaskan peran koperasi dalam bidang ekonomi yaitu: (1) membangkitkan semangat kemanusiaan untuk usaha koperasi dalam bentuk pelayanan bagi masyarakat dan bukan mencari keuntungan; (2) pembagian sisa usaha tidak berdasarkan pada modal, tetapi sesuai jasa dan partisipasinya; (3) mengurangi monopoli dalam berbentuk perkumpulan modal, sebagai usaha bersama untuk meningkatkan kesejateraan anggota koperasi; (4) menawarkan barang dan jasa yang lebih murah sebagai pelayanan utama koperasi dari pada perusahaan; (5) keuntungan yang diperoleh tidak dinikmati oleh ketua/pengurus, tetapi diperuntukan bagi anggota sesuai dengan partisipasi; (6) mengurangi usaha niaga, dan melingdungi konsumen dari iklan yang membingunkan serta menghapuskan tata niaga yang tidak benar dan jujur; (7) mengutamakan kejujuran dan keterbukaan untuk semua anggota agar mengetahui keuangan serta mengawasinya; (8) koperasi menjaga keseimbangan antara permintaan dan penawaran,serta menghidari penumpukan barang dengan tujuan untuk mencari keuntungan; (9) masyarakat dilatih memafaatkan pendapatan secara baik untuk memenuhi kebutuhan hidaup dan hemat agar dapat meningkatkan kesejahteraan.

Fungsi koperasidari aspek ekonomi dan sosial mencerminkan adanya proses pendidikan nonformal yang berlangsung hingga mampu membentuk perilaku masyarakat sesuai dengan konteks ekonomi dan sosial yang lebih demokratis. Peran koperasi dari sisi ekonomi sebagai pembuktian bahwa kegiatan koperasi berlangsung dalam 
formula pendidikan nonformal. Sasaran yang dikehendaki dalam bidang ekonomi memberi sinyal tentang proses pendidikan nonformal yang berlangsung dalam kegiatan koperasi, baik sejak awal penentuan hingga kegiatan operasionalnya.

Dikaji secara mendalam pelatihan yang diberikan untuk koperasi/KUD dan prakoperasi merupakan suatu upaya pemberdayaan masyarakat oleh Dinas Koperasi Kabupaten Buru melalui gerakan koperasi, yang dimulai dengan kelompok-kelompok organisasi masyarakat yang hendak mendirikan koperasi. Sebagai suatu bentuk pemberdayaan masyarakat dalam meningkatkan ekonomi keluarga dan masyarakat.

Suryono dan Sumarno (2012, p.142), menjelaskan konsep pemberdayaan masyarakat diperkenalkan sebagai upaya membantu masyarakat untuk melakukan sebuah perubahan menuju kehidupan yang lebih berkualitas baik untuk diri, keluarga maupun lingkungan sekitarnya, maka model pendampingan lebih memiliki makna kesetaraan (equlity).

Pemerintah tidak lepas tangan dalam pemberdayaan masyarakat, oleh sebab itu pemerintah secara terus-menerus melakukan pembinaan untuk masyarakatmelalui pendidikan dan pelatihan dengan tujuan agar masyarakat memilki kecakapan hidup atau lifeskill. Berdasarkan Undang Undang Nomor 20 Tahun 2003 tentang Sistem Pendidikan Nasional, pendidikan nonformal adalah jalur pendidikan diluar pendidikan formal yang dapat dilaksanakan secara terstruktur dan berjenjang. Pendidikan informal adalah jalur pendidikan keluarga dan lingkungan masyarakat. Untuk itu kedua jalur pendidikan tersebut terdiri atas keluarga, kelompok belajar, lembaga kursus, pelatihan, majelis taklim dan pusat kegitan belajar masyarakat (PKBM).

Sistem pendidikan yang bersifat nonformal disusun secara sistematis dan terorganisir, yang diselenggarakan di luar sistem persekolahan, serta diperuntukan kepada individu, kelompok dan masyarakat, agar dapat meningkatkan pendidikan dan ketrampilan bagi masyarakat baik secara fisik maupun nonfisik sehingga masyarakat terbebas dari kebodohan, kemiskinan dan keterbelakangan.

Pendidikan dan keterampilan untuk kelompok prakoperasi dipandang sangat penting dalam menghadapi perkembangan kondisi ekonomi masyarakat yang semakin sulit. Masyarakat dihadapkan dengan keadaan ekonomi yang mengalami perubahan dari waktu ke waktu yang sangat tinggi, sehingga masyarakat sangat sulit untuk memenuhi kebutuhan hidupnya sehari-hari. Upaya yang dilakukan dapat bermanfaat, serta dipandang sebagai aktifitas ekonomi yang siap untuk menghadapi suatu persaingan yang dapat membawa masyarakat menuju kesejahteraan hidup yang lebih baik. Untuk mengembangkan masyarakat serta meningkatkan kebutuhan masyarakat, melalui pengembangan sumber daya manusia yang diselenggarakan baik pihak swasta maupun pemerintah, telah bersama-sama melakukan suatu upaya yang bermanfaat bagi masyarakat hal ini memberikan pendidikan dan pelatihan yang berupa kecakapan hidup atau lifeskill.

Sehingga dalam penelitian lebih tertarik melihat permasalah tentang bagaimana proses pembentukan kelompok prakoperasi di Kecamatan Namlea, faktor-faktor apakah yang menjadi pendukung dan penghambat pelatihan kelompok prakoperasi di Kecamatan Namlea, dan bagimana dampak pelatihan terhadap anggota kelompok prakoperasi di Kecamatan Namlea.

\section{METODE}

Penelitian inimerupakan penelitian kasus yang dilaksanakan di Kecamatan Namlea Kabupaten Buru. Penelitian dilaksanakan pada bulan Februari sampai dengan bulan April 2013.

Penelitian ini merupakan penelitian kualitatif naturalistik dengan subjek penelitian sebanyak 4 unit kelompok prakoperasi dikecamatan Namlea, dan yang objek dalam penelitian ini adalah anggota prakoperasi yang telah mengikuti pendidikan dan pelatihan pada tahun 2012 serta pihak penyelenggara pelatihan.

Metode pengumpulan data yang digunakan dalam penelitian adalah observasi, wawancara, dan dokumentasi. Dan peneliti 
sendiri sebagai instrumen kunci yang secara langsung terun ke lapangan untuk mengumpulkan data dengan menggunakan beberapa data instrumen tambahan lain. Instrumen tambahan adalah lembaran pengamatan, pedoman wawancara, dokumentasi.

Teknik analisis data dalam penelitian ini menggunakan model interaktif, yang dimuali dari pengumpulan data, reduksi data, penyajian data dan penarikan kesimpulan. Untuk mendapatkan keabsahan data dalam penelitian ini,menggunakan teknik trianggulasi, perpanjangan pengamatandan meminta pendapat ahli.

\section{HASIL DAN PEMBAHASAN}

\section{Hasil}

Proses Pembentukan Kelompok Prakoperasi di Kecamatan Namlea

Hasil wawancara dengan penyelenggara dan peserta pelatihandiperoleh data bahwa proses pembentukan kelompok prakoperasi di Kecamatan Namlea, pembentukannya dari kelompok masyarakat yang ada dalam organisasi masyarakat maupun tidakdan diprakasasi oleh tokoh masyarakat. Pelaksanaan pelatihan bagi kelompok prakoperasi merupakan suatu upaya pemberdayaan masyarakat oleh Dinas Koperasi Kabupaten Buru melalui gerakan koperasi yang dimulai dengan kelompok kelompok organisasi masyarakat yang hendak mendirikan koperasi. Tujuan pelaksanaan pelatihan manajemen pengelolaan prakoperasi adalah untuk meningkatkan Sumber Daya Manusia dalam gerakan koperasi khususnya kepada pengurus, pengawas pengelolah dan anggota prakoperasi. Sehingga terwujud koperasi atau KUD yang tangguh, kuat dan mandiri serta memiliki daya saing tinggi dan mampu memberikan pelayanan yang maksimal bagi anggota dan masyarakat umumnya, serta dapat memberikan kontribusi positif dalam meningkatkan pendapat asli daerah (PAD).

Proses pembentukan kelompok prakoperasi di Kecamatan Namlea tidak ada campur tangan dari Dinas Koperasi. Kelompok yang terbentuk melapor di Dinas Koperasi, selanjutnya Dinas Koperasi Kabupaten
Buru menindak lanjuti laporan tersebut dengan melakukan sosialisasi kepada masing-masing kelompok prakoperasi yang telah mendaftarkan kelompok prakoperasi di Dinas Koperasi. Sosialisasi dari Dinas Koperasi bertujuan untuk memberikan pemahaman kepada masyarakat khususnya yang mendirikan prakoperasi tentang struktur kepengurusan, selain itu sosialisasi dilakukan untuk memberikan informasi tentang persyaratan mendirikan prakoperasi dan syarat prakoperasi menjadi koperasi yang berbadan hukum.

Selain itu Dinas Koperasi Kabupaten Buru melakukan pelatihan-pelatihan yang diberikan kepada koperasi KUD mapun prakoperasi yang dilaksanakan di Kecamatan Namlea, diberikan secara berasamaan dengan tidak mambeda-bedakan antara koperasi/KUD maupun prakoperasi. Dengan maksud agar semua peserta memiliki pemahaman yang saman dalam mengelola usaha.

Untuk itu Kurikulum pelatihan manajeman pengelolaan koperasi/KUD dan prakoperasi sama, namun Dinas Koperasi Buru masih mengunakan kurikulum yang belum terstruktur atau bersifat sementara dan disesuaikan dengan kebutuhan koperasi/KUD dan prakoperasi. Tujuan dilaksanakan kegiatan pelatihan manajemen pengelolaan koperasi/KUD dan prakoperasi adalah untuk meningkatkan Sumber Daya Manusia dalam gerakan koperasi khususnya kepada pengurus, pengawas pengelola dan anggota koperasi.

Biaya pelatihan yang digunakan Dinas Koperasi Kabupaten Buru bersumber dari APBD Kabupatan Buru. Sasaran pelatihan adalah (1) terwujudnya pengurus, pengawas, pengelola dan anggota koperasi yang professional sesuai dengan kebutuhan yang diinginkan, (2) terwujudnya koperasi yang kuat, tangguh dan mandiri serta memiliki daya saing yang tinggi, (3) terciptanya koperasi yang mampu memberikan pelayanan secara maksimal serta dirasakan langsung oleh anggota koperasi dan masyarakat umumnya, (4) terciptanya koperasi yang dapat memberikan kontribusi positif bagai peningkatan pendapatan asli daerah (PAD). 
Selain itu sarana prasarana penunjang pelatihan masih sangat terbatas dan seadanya.

Materi pelatihan yang diberikan oleh fasilitator dari Dinas Koperasi Kabupaten Buru meliputi pelatihan manajemen pengelolaan koperasi,fungsi manajemen dalam pengembangan koperasi, Pokok-pokok kebijakan dan program pemerintah dalam pemberdayaan koperasi dan UKM, Fungsi menajemen dalam meningkatkan pengembangan koperasi, dan kewirausahaan. Pendidikan dan pelatihan yang dilaksanakan oleh Dinas Koperasi Buru hanya diperuntukan bagi anggota kelompok prakoperasi atau pengurus. Rata-rata anggota kelompok prakoperasi yang mengikuti pelatihan memiliki motivasi sangat tinggi, sebab pelatihan dapat menambah pengetahuan dan keterampilan peserta serta membangkitkan semangat usaha dari masing-masing anggota prakoperasi.Waktu pelatihan belum sesuai dengan perencanaan yang telah dibuat oleh Dinas Koperasi, tetapi pelaksanaan pelatihan disesuaikan dengan biaya yang dialokasikan oleh pemerintah daerah Kabupaten Buru yang diperoleh dari APBD. Sehingga waktu pelatihan rata-rata kurang lebih hanya 3 hari.

Fasilitator/narasumber mempunyai peran yang sangat penting untuk keberlangsungan pelatihan manajemen pengelolaan koperasi. Fasilitator/narasumber yang memberikan materi pelatihan semua berasal dari Dinas Koperasi Kabupaten Buru telah memiliki pengetahuan maupun keterampilan khusus yang memadai. Fasilitator yang berada dalam lingkup Dinas Koperasi Kabupaten Buru sudah memenuhi kriteria baik dari segi pendidikan formalnya maupun pendidikan nonformal yang pernah diikutinya.

Anggota kelompok prakoperasi memiliki latar belakang kehidupan dan ekonomi yang beragam. Ada petani minyak kayu putih, karyawan bengkel, ibu rumah tangga, pengungsi korban kerusuhan Ambon, nelayan, pedagang, dan ada juga pegawai. Anggota kelompok prakoperasi mengakui kehidupan ekonomi sebelum menjadi anggota prakoperasi sangat sederhana tidak ada yang berlebihan. Namun setelah meng-ikuti pelatihan anggota kelompok prakoperasi dapat memiliki pengetahuan dan keterampilan dalam mengelolah usaha, sehingga anggota yang sudah memiliki usaha dapat menggunakan strategi dan manajemen yang lebih baik lagi dalam megembangkan usahanya menjadi lebih maju. Rata-rata peserta yang sudah mengikuti pelatihan dan sudah mempunyai usaha, usahanya menjadi lebih baik atau mengalami kemajuan. Sedangkan anggota yang belum memiliki usaha terinspirasi untuk membuka usaha sesuai dengan kemampuan masing-masing dan lingkungan tempat anggota berdomisili dengan tujuan agar dapat meningkatkan perekonomian keluarga.

Faktor Pendukung dan Penghambat Pelatihan Prakoperasi di Kecamatan Namlea.

Faktor pendukung Pelaksanaan pelatihan sehingga pelatihan dapat berlangsung dengan lancer didukung oleh biaya yang telah disediakan pemerintah daerah Kabupaten Buru untuk pelaksanaan pelatihan bagi koperasi/KUD dan prakoperasi, serta motivasi dari anggota yang sangat tinggi,dengan mengikuti pelatihan dapat menambah pengetahuan, dan keterampilan anggota prakoperasi dalam mengelola usaha dan meningkatkan usahanya sehingga dapat meningkatkan perekonomian keluarga. Selain itu yang menjadi faktor penghambat pelaksanaan pelatihan yakni anggota kelompok prakoperasi ada yang mempunyai pekerjaan tetap sehingga tidak dapat mengikuti pelatihan, kesibukan anggota prakoperasi mengurusi usaha dan masalah dalam keluargaserta tingkat pendidikan yang dimiliki oleh anggota prakoperasi yang tergolong rendah sehingga sulit mengerti memehami materi pelatihan yang diberikan oleh fasilitator.

Dampak Pelatihan terhadap Kelompok Prakoperasi di Kecamatan Namlea

Dampak Pelatihan bagi anggota prakoperasi yang telah mengikuti pelatihan, diantaranya adalah peserta yang mau membuka usaha disesuaikan dengan kemampuan masing-masing, meningkatkan dan memperbesar usaha, serta saling membelajarkan diantara yang sudah mengikuti pelatihan dengan yang belum mengikuti 
pelatihan, sehingga terjadi peningkatan kesejateraan ekonomi pada masing-masing anggota. Sedangkan dampak negatifnya yakni kurangnya transparasi pengurus pada anggota dapat meneyebabkan ketidakpercayaan anggota peda pengurus prakoperasi, selain itu pengurus prakoperasi sibuk dengan usaha pribadinya jadi mengabaikan tugasnya sebagai pengelolah prakoperasi mengakibatkan sebagian prakoperasi menjadi macet.

\section{Pembahasan}

Terkait dengan proses pembentukan kelompok prakoperasi di Kecamatan Namlea, proses pembentukan kelompok prakoperasi diprakarsai oleh tokoh-tokok masyarakat baik yang ada dalam organisasi maupun yang tidak tergabung dalam organisasi. Langkah-langkah pembentukan kelompok prakoperasi diawali dengan pertemuan untuk berembuk tentang siapa saja yang mau bergabung dalam kelompok prakoperasi, penentuan nama koperasi, pengurus koperasi, dan penentuan jumlah simpanan wajib serta simpanan pokok. Selanjutnya kelompok prakoperasi melaporkan ke Dinas Koperasi sebagai kelompok prakoperasiyang baru dibentuk. Dinas Koperasi menindak lanjuti laporan tersebut dengan memberikan sosialisasi kepada kelompok prakoperasi untuk memperjelas bidang usaha yang dikelola oleh prakoperasi, yang kemudian diikuti dengan pelatihan bagi pengurus kelompok prakoperasi.

Pelaksanaan pelatihan bagi kelompok koperasi, KUD dan prakoperasi belum memiliki kurikulum terstruktur. Kurikulum yang digunakan disesuaikan dengan kebutuhan, tujuan dan sasaran yang di inginkan oleh kelompok koperasi/KUD maupun kelompok prakoperasi agar memiliki pengetahuan dan keterampilan dalam mengelola usaha. Perumusan tujuan pelatihan tidak melibatkan peserta pelatihan atau koperasi/ KUD dan prakoperasi. Sebelum pelatihan Dinas Koperasi melakukan analisis kebutuhan dilapangan untuk mengetahui permasalahan yang dihadapi oleh kelompok koperasi/KUD dan prakoperasi.

Hasil yang diperoleh di lapangan dijadikan dasar untuk perumusan tujuan pelatihan dan dimasukan kedalam tujuan instruksional umum dan tujuan instruksional khusus. Namun dalam pelaksanaan pelatihan tersebut Dinas Koperasi Kabupaten Buru belum memiliki sarana dan prasarana pelatihan yang baik.

Pelatihan dilaksanakan yang oleh Dinas Kabupaten Buru bagi pengurus atau anggota koperasi/KUD dan prakoperasi dalam bentuk Diklat yang dilaksanakan secara bersamaan. Dengan tujuan agar peserta yang mengikuti pelatihan memiliki kesungguhan dalam mengikuti diklat sehingga mereka dapat memiliki pendidikan dan keterampilan dalam mengelolah usaha. Materi diklat disesuaikan dengan kebutuhan di lapangan sehingga tidak ada kurikulum yang terstruktur dalam pelatihan. Pokok bahasan dalam pelatihan disesuaikan dengan indikator pencapaian agar dapat meningkatkan Sumber Daya Manusia dan mewujudkan koperasi yang kuat, tangguh ulet serta memberikan kontribusi bagi anggota koperasi/KUD maupun prakoperasi dalam mengelola usaha sehingga dapat meningkatkan ekonomi anggota, serta memberikan kontribusi bagi daerah.

Waktu pelatihan terbatas karena disesuaikan dengan anggaran yang dikeluarkan oleh Pemerintah Daerah Kabupaten Buru. Fasilitator yang memberikan diklat memiliki tingkat pendidikan S-1 dan pernah mengikuti pelatihan, sehingga fasilitator mampu mengidentifikasi kebutuhan dari peserta, dan mampu merancang pelatihan yang baik, serta dapat memberikan pelatihan yang maksimal kepada peserta pelatihan sehingga memberikan manfaat bagi peserta.

Kegiatan ekonomi yang dijalankan oleh kelompok prakoperasi di Kecamatan Namlea Kabupaten Buru bergerak dibidang simpan pinjam, dengan tujuan agar anggotanya dapat meminjam modal dari prakoperasi untuk meningkatkan usahanya bagi anggota prakoperasi yang sudah memiliki usaha dan bagi anggota yang belum memiliki usaha agar termotivasi untuk membuka usaha sesuai dengan keinginannya, dengan satu harapan agar masingmasing anggota mempunyai usaha.

Keberhasilan pelaksanaan pelatihan dapat dilihat dengan adanya perubahan 
perekonomian peserta pelatihan dan anggota kelompok prakoperasi setelah mengikuti pelatihan. Walaupun tidak semua anggota kelompok prakoperasi mengikuti pelatihan, namun anggota kelompok prakoperasi yang sudah mengikuti pelatihan membelajarkan anggota yang belum mengikuti pelatihan tentang bagaimana memenej usaha dan mengelolah usaha supaya berkembang. Sehingga rata-rata anggota prakoperasi memiliki tingkat kesejateraan lebih baik setelah menjadi anggota prakoperasi dibandingkan sebelum menjadi anggota prakoperasi.

Selain itu keberhasilan pelaksanaan pelatihan juga karena didukung oleh biaya dari pemerintah daerah Kabupaten Buru lewat Dinas Koperasi, kerja sama antara peserta pelatihan dimana anggota yang sudah faham akan membelajarkan kepada peserta yang belum faham, memiliki fasilitator/narasumber pelatihan yang dapat diandalkan baik segi pendidikan maupun pengalaman di bidang masing-masing, dan didukung oleh para peserta pelatihan yang bersungguh-sungguh untuk belajar agar dapat menambah pengetahuan dan keterampilan dalam mengelola koperasi maupun usaha masing-masing anggota.

Kendala-kendala yang mempengaruhi pelaksanaan pelatihan adalah faktor usia peserta diklat yang beragam ada yang muda juga ada yang sudah tua dan tingkat pendidikan yang beragam mulai SMP sampai $S_{1}$, hal ini sangat berpengaruh dalam memahami materi dan berinteraksi selama pelatihan. Selain itu Waktu pelatihan yang terbatas karena biaya pelatihan yang terbatas dan saranadan prasarana yang belum baik, serta kondisi alam.

Kontribusi pelatihan terhadap kelompok prakoperasi yang dilaksanakan oleh Dinas Koperasi Kabupaten Buru di Kecamatan Namlea adalah dapat meningkatkan sumber daya manusia (SDM), membangkitkan semangat untuk mendirikan koperasi dan berwirausaha, dan turut membantu masyarakat khususnya anggota kelompok prakoperasi dalam meningkatkan ekonomi keluarganya.

Selain itu ada dampak positf yang dirasakan oleh anggota prakoperasi adalah masing-masing anggota mempunyai kegiatan yang bergerak dalam bidang usaha, yang dapat meningkat ekonomi keluarga dari yang sebelumnya sehingga dapat meningkatkan kesejahteraan ekonomi keluarga. Sedangkan dampak negatif yang dialami oleh kelompok prakoperasi setelah mengikuti pelatihan yakni kurangnya transparasi pengurus menimbulkan rasa curiga anggota kepada pengurus dan kesibukan pengurus pada usaha masing-masing membuat pengurus lalai dalam mengurus prakoperasi sehingga ada prakoperasi yang mengalami kemunduran bahkan macet.

\section{PENUTUP}

\section{Simpulan}

Berdasarkan hasil analisis dan pembahasan dapat disimpulkan bahwa (1) input kelompok pra kopresai dibentuk dari organisasi kelompok masyarakat yang memiliki pandangan yang sama, dengan bantuan dari Dinas Koperasi lewat sosialisasi tentang proses pembentukan prakoperasi, syarat-syarat yang harus dipenuhi untuk mendirikan prakoperasi, memiliki tujuan dan sasaran serta kurikulum, di biayai oleh PEMDA Kabupaten Buru, namun sarana dan prasarana belum memadai. Proses pelatihan dilaksanakan dalam bentuk diklat, dapat memberi motivasi bagi anggota pelatihan, materi sesuai dengan kebutuhan anggota pra koperasi, waktu pelatihan sangat singkat, dan fasilitator dari Dinas Koperasi memadai. Output menunjukan setelah menjadi anggota prakoperasi dan mengikuti pelatihan dapat menumbuhkan keinginan berwirausaha bagi peserta pelatihan yang belum memiliki usaha dan memberikan motivasi bagi yang sudah memilki usaha untuk meningkatkan usahanya. (2) faktor pendukung pelatihan yakni dana pelatihan, fasilitator/ narasumber, motivasi anggota prakoperasi mengikuti pelatihan untuk menambah pengetahuan dan keterampilan mengelola usaha. Faktor penghambat, usia terlalu tua, tingkat pendidikannya rendah, masalah dalam keluarga, waktu pelaksanaan pelatihan sering terlambat dari jadwal yang ditetapkan, sarana prasarana yang kurang memadai, keterbatasan kemampuan anggota pra- 
koperasi melakukan interaksi, tempat tinggal jauh dari tempat pelatihan. (3) dampak pelatihan dapat meningkatkan pengetahuan dan keterampilan anggota dalam mengelola usaha sehingga dapat meningkatkan perekonomian anggota prakoperasi. Dampak negatifnya tidak adanya transparansi pengurus dengan anggota dalam mengelolah keuangan, menyebabkan kurangnya kepercayaan anggota terhadap pengurus sehingga prakoperasi tidak dapat berkembang.

\section{Saran}

Perhatian Dinas Koperasi Kabupaten Buru kepada organisasi masyarakat yang hendak mendirikan prakoperasi, serta mempercepat prakoperasi menjadi koperasi yang memiliki kekuatan hukum/berbadan hukum. Perlunya penambahan biaya dari Pemerintah Daerah Kabupaten Buru yang diperuntukan bagi pelatihan koperasi/KUD dan prakoperasi sehingga pelaksanaannya dapat berlangsung sesuai dengan rencana yang dibuat. Waktu pelatihan harus ditingkatkan dari yang sebelumnya agar peserta yang mengikuti pelatihan dapat memahami materi dengan baik, serta menyediakan.Ke depan Dinas Koperasi Kabupaten Buru harus memiliki sarana dan prasarana pelatihan yang baik agar peserta yang mengikuti pelatihan merasa nyaman selama pelatihan berlangsung.

\section{DAFAR PUSTAKA}

Baswir, Revrison. (2012). Koperasi Indonesia. Yogyakarta: BPFE

Bhatti, M Awais and Kaur, Sharan. (2010). The role of individual and training design factors on training transfer. The Journal of European Industrial Training, Vol. 34. Diakses dari www.emeraldinsight.com/ozog0590.htm. pada tanggal 5 Januar 2013.

Hamid, Edy Suandi. (2012). Dinamika ekonomi Indonesia. Yogyakarta: UII Press.

Huraerah, Abu. (2008). Pengorganisasian dan pengembangan masyarakat model dan strategi pembangunan berbasis kerakyatan. Bandung: Humaniora.

Kamil, Mustofa. (2012). Model pendidikan dan pelatihan: konsep dan aplikasi. Bandung: Alfabeta.

Mujiman, Haris. (2011). Manajemen pelatihan berbasis belajar mandiri. Yogyakarta: Pustaka Pelajar Offset

Republik Indonesia. (2009). UndangUndang Republik Indonesia Nomor 11 Tahun 2009 Tentang Kesejahteraan Sosial.

Rintuh, Cornelis \& Miar. (2005). Kelembagaan dan ekonomi kerakyatan. Yogyakarta: BPFE-Yogyakarta.

Salvatore, Dominick. (2006). Mikro ekonomi Jakarta: Erlangga

Siagian, Sondang P. (2008). Manajemen sumber daya manusia. Jakarta: Bumi Aksara.

Suharto, Edi. (2010). Membangun mayarakat memberdayakan rakyat, (kajian strategis pembangunan kesejahteraan (sosial E pekerjaan sosial). Bandung: Refika Aditama.

Suryono, Yoyon \& Sumarno. (2012). Pembelajaran kewirausahaan masyarakat. Yogyakarta: Aditya media. 